\title{
Government as a Social Machine in an Ecosystem
}

\author{
Thanassis Tiropanis \\ University of Southampton \\ Electronics and Computer Science \\ Web and Internet Science Group \\ University Road, Southampton \\ SO17 1XS, UK \\ tt2@ecs.soton.ac.uk
}

\author{
Anni Rowland-Campbell \\ Australian and New Zealand \\ School of Government \\ anni@intersticia.com
}

\author{
Wendy Hall \\ University of Southampton \\ Electronics and Computer Science \\ Web and Internet Science Group \\ University Road, Southampton \\ SO17 1XS, UK \\ wh@ecs.soton.ac.uk
}

\begin{abstract}
The Web is becoming increasingly pervasive throughout all aspects of human activity. As citizens and organisations adopt Web technologies, so governments are beginning to respond by themselves utilising the electronic space. Much of this has been reactive, and there is very little understanding of the impact that Web technologies are having on government systems and processes, let alone a proactive approach to designing systems that can ensure a positive and beneficial societal impact. The ecosystem which encompasses governments, citizens and communities is both evolving and adaptive, and the only way to examine and understand the development of Web-enabled government, and its possible implications, is to consider government itself as a "social machine" within a social machine ecosystem. In this light, there are significant opportunities and challenges for government that this paper identifies.
\end{abstract}

\section{Categories and Subject Descriptors}

K.4.0 [Computers and Society]: General, K.4.3 [Computers and Society]: Organizational Impacts, J.1 [Computer Applications]: Administrative Data Processing - Government, H.5.3 [Information Systems and Applications] Information Interfaces and Presentation - Group and Organization Interfaces

\section{Keywords}

Social Machines Ecosystems, e-Government.

\section{THE CHANGING SHAPE OF GOVERNMENT AND CITIZEN INTERACTION}

"An ecosystem is a community of living organisms ... in conjunction with the nonliving components of their environment. ... (D)efined by the network of interactions among organisms, and between organisms and their environment." [1]

Government exists as a mechanism for collective action in order to fulfill citizen and community needs, and it does this by articulating societal values through policies and programmes

Copyright is held by the International World Wide Web Conference Committee (IW3C2). IW3C2 reserves the right to provide a hyperlink to the author's site if the Material is used in electronic media.

WWW'14 Companion, April 7-11, 2014, Seoul, Korea.

ACM 978-1-4503-2745-9/14/04.

http://dx.doi.org/10.1145/2567948.2578837 which rely on the currency of information. As such it is essentially a "system" within an "ecosystem", which operates through the interaction of citizen behaviours and administrative processes driven by the collection, curation and management of information.

In past eras the so-called "machinery of government" [2] had characteristics that were determined by the properties of information in the physical world. As information becomes digital in format so government processes are slowly changing and adapting to the affordances of digital systems, but this is resulting in some fundamental changes in the relationships which exist, and an opportunity to challenge some of the established thinking around the role of "The State". The UK's "Power of Information" report argued that government should "grasp the opportunities that are emerging in terms of the creation, consumption and re-use of information", in essence, government in the digital age can, and should, be "reinvented" [3].

The first phase of this "reinvention" was where governments created an electronic publishing space on the Web and sought to transfer some services online; the second phase has seen governments respond to the adoption of Web 2.0 technologies by seeking to more effectively engage with citizens through Social Media as an online "dialogue"; the third phase sees governments attempting to become more responsive, dynamic and "open" through trying to develop interoperability between government processes, and adopt a "citizen centric" approach to information and communications through an intelligent use of data. All of these may be seen as the building blocks of "e" or "electronicgovernment", but this is a simplistic way of viewing government in the digital age because it does not provide:

- An understanding of the fragility and risks of eGovernment models which rely on both the data generated by citizens, community and business, and the intermediary role of third party systems as exchange "platforms";

- Any way of identifying, studying, and, if need be, preventing, the side effects which may impact on the ecosystem as a whole as it interacts with the broader societal and business context; or

- The ability to understand the links between mechanisms of efficient citizen engagement and policy formulation, and from there to intentionally design socio-technical systems which have positive societal impacts.

Governments exist within ecosystems of people and organisations, and, as these systems become more interconnected 
via digital interaction technologies a new model is required to describe their development, operation and implications. One such model is that of the "social machine".

\section{GOVERNMENT AS A SOCIAL MACHINE}

The "social machine" has been described as a system "where human and computational intelligence coalesce in order to achieve a given purpose." [4] Social machines can be seen as the interaction of individual action and co-ordination, mediated and enabled by the "shared communication substrate of the Web" [5]. For governments this translates as "collaboration platforms - for organizing work at a distance that could translate into ways to get all hands on deck to undertake action together. " [6]

At a base level the promise of "Web 2.0" technologies lies in the efficient architecture of a socio-technical system within which citizens provide their data (in all formats, structured and unstructured) and, in response, governments should be better able to understand societal needs and, as a result, more effectively and efficiently deliver services and develop policy. The hope is that instead of "vending machine government", where we pay our taxes and expect services in return, the role of government is more like being the manager of the marketplace, or the bazaar, where the community exchanges goods and services and actively participates, leading to enhanced democratic processes [7].

Studying government as a social machine allows us to put every aspect of Web-mediated citizen engagement with government in perspective, and better explore opportunities for collective action, problem solving and societal impact in a holistic way, or real scenarios where "people will not see their influence limited to elections every four to five years; rather, citizens will exercise permanent influence through constant suggestions, ideas, and contributions, all organized over the internet." [8]

\section{GOVERNMENT IN A SOCIAL MACHINE ECOSYSTEM}

Government exists through the "relationships" with those who are "governed" - citizens, businesses and communities. Many of the processes that government is adopting rely on other social machines, including social machines such as Twitter or Ushahidi. This adds the extra dimension of government as a social machine within an ecosystem of social machines and brings forward a number of significant questions that need to be addressed:

1. How does Government acting (or viewing) itself as part of a "social machine" ecosystem change the way that it interacts with citizens, businesses and communities?

2. How are Government processes and their sustainability affected by existing social machines maintained by other parties? (e.g. by Twitter, Wikipedia, Ushahidi)?

3. How can governments best safeguard the privacy and security of citizen information in this ecosystem as a core component of the "social compact"?

4. How should Government redefine its role, responsibilities and processes) within the complex and interdependent environment of social machines?

\section{CONCLUSION}

Governments around the world are seeking to understand, leverage and proactively manage socio-technical systems in order to more effectively and efficiently meet community needs.
However, "(m)ost of the failings of government can be connected to the fundamental assumption that humans are rational creatures and the inherent structural biases toward mechanical processes and short-term thinking. ... We need designers, political scientists, and social activists ... to take up the challenge of designing new systems of governance ... that are open, accessible, and learning. They need to embody the latest thinking about how the world works, how people work, and how we can use our technologies to make life better for all." [9]

That "latest thinking" should embrace the potential and promise of "emergent systems", in particular the concept of "social machines", in order to better respond to the dynamic nature of society and to accommodate the complexity of the required interactions and services. Government can then be imagined not a fixed and rigid edifice, but rather as a dynamic and emergent [10] social machine, within an ecosystem of other ancillary and complementary social machines, and its systems and processes evolve as to societal needs.

\section{ACKNOWLEDGEMENTS}

Part of this work is supported under SOCIAM: The Theory and Practice of Social Machines. The SOCIAM Project is funded by the UK Engineering and Physical Sciences Research Council (EPSRC) under grant number EP/J017728/1 and comprises the Universities of Southampton, Oxford and Edinburgh.

\section{REFERENCES}

[1] Wikipedia, http://en.wikipedia.org/wiki/Ecosystem, viewed $12^{\text {th }}$ February, 2014.

[2] Mills, J. S. (1861) "Considerations on Representative Government", Chapter V. Retrieved 14 January, 2014 from http://www.constitution.org/jsm/rep_gov.htm

[3] Allan, R. (2009). The Power of Information Taskforce Report. London, Power of Information Task Force. Power of Information Task Force.

[4] Shadbolt, N., D. A. S. Smith, et al. (2013) "Towards a classification framework for social machines." WWW2013 SOCIAM workshop. Rio de Janeiro, Brazil.

[5] SOCIAM PROJECT. (2011). "The Theory and Practice of Social Machines." Retrieved 14 January 2014, 2014, from http://www.sociam.org/about.

[6] Novack, B. S. (2013). "Gov 3.0 Syllabus." Retrieved 3rd September, 2013, 2013, from http://mehan.github.io/gov30.html

[7] Raymond, E. (2000) "The Cathedral and the Bazaar." Retrieved from http://www.catb.org/ esr/writings/cathedralbazaar/cathedral-bazaar/index.html, 14 January 2014.

[8] Bohnen, J. and J.-F. Kallmorgen (2009) "How Web 2.0 is Changing Politics." Internationale Politik, July/August. Retrieved from http://www.atlanticcommunity.org/index/articles/view/How_Web_2.0_is_Chang ing_Politics 14 January 2014.

[9] Dunagan, Jake. “The Future of Government". Retrieved from http://www.good.is/post/the-future-ofgovernment/?utm_source $=$ feedburner\&utm_medium $=$ feed\& utm_campaign $=$ Feed $\% 3 \mathrm{~A}+\operatorname{good} \% 2 \mathrm{Flbvp}+\% 28 \mathrm{GOOD}+\mathrm{Mai}$ $\mathrm{n}+\mathrm{RSS}+$ Feed $\% 29,19$ July 2010.

[10] De Roure, D., C. Hooper, et al. (2013). Observing Social Machines Part 1: What to Observe? WWW2013 - SOCIAM workshop. Rio de Janeiro, Brazil. 